\title{
KONSEP KEPERLUAN KEIZINAN DARIPADA WALI DALAM PERNIKAHAN WANITA BERSTATUS ANAK DARA MENURUT FIQH MUNAKAHAT
}

\author{
Mohammad Azam Hussain \\ School of Law, College of Law, \\ Government and International Studies, \\ Universiti Utara Malaysia \\ hmazam@uum.edu.my
}

Received: 24 October 2017 Accepted: 15 December 2018 Published Online: 24 December 2018

\section{ABSTRAK}

Fuqaha berbeza pendapat akan keperluan keizinan wali dalam sesuatu akad pernikahan. Persoalan timbul, apakah keizinan daripada wali itu diperlukan dalam pernikahan? Ataupun seseorang perempuan itu berhak untuk menikahkan dirinya sendiri. Artikel ini membincangkan konsep perwalian dari perspektif fiqh melibatkan definisi, dalil syarak, syarat-syarat dan lain-lain yang berkaitan. Berdasarkan karya-karya fiqh klasik, kaedah analisis kandungan dan perbandingan digunakan bagi melihat sejauh mana berlaku perbezaan pandangan antara fuqaha dalam hal ini. Kajian mendapati bahawa, majoriti fuqaha berpandangan bahawa keizinan wali merupakan syarat kepada kesahihan sesuatu akad pernikahan bagi perempuan berstatus anak dara. Dalam kes perempuan berstatus janda, keizinan daripadanya juga diperlukan.

Kata kunci: Wali, Wali mujbir, Fiqh munakahat, Anak dara, Janda.

\begin{abstract}
Muslim jurists have different views on the requirement of a wali's consent in a marriage. A question arises, is the consent of the wali required in marriage? Or, has a woman the right to marry herself off?
\end{abstract}


This article discusses the concept of wali from the fiqh perspective which involves definition, proof according to Islamic religious law, conditions and other related matters. Based on clasical fiqh literature, content analysis and comparison methods were used to determine to what extent views among Muslim jurists differed in this regard. The findings showed that the majority of Muslim jurists viewed that consent from the wali is the condition for the validity of marriage in the case of women who are virgins. Consent from the wali is also required in the case of women who are widows.

Keywords: Wali, Wali mujbir, Fiqh munakahat, Virgin, Widow.

\section{PENGENALAN}

Perkataan wali dalam bahasa Arab kebiasaannya digunakan dengan rangkai kata "al-wilayah fi al-nikah aw al-ziwaj". Pengertian "alwilayah" ini boleh dilihat dari aspek bahasa dan istilah. Perkataan "al-wilayah"1 berasal daripada bahasa Arab yang merupakan kata dasar (masdar) daripada "wa-li-ya", yang memberi erti menyayangi, menolong, menguasai dan memimpin. Juga bermakna kesanggupan bertindak, mengurus atau mempunyai kekuasaan mentadbir sesuatu dan memperwalikan seseorang perempuan. Perkataan "alwali" pula merujuk orang yang mengurus, memelihara atau orang yang bertanggungjawab ke atas sesuatu. Rangkai kata "wali almar'ah" pula membawa maksud orang yang berkuasa (berhak) mengakadnikahkan seseorang perempuan.

Dari segi istilah, pelbagai definisi tentang perwalian diberikan oleh para cendekiawan Islam. Antaranya:

(a) Wahbah al-Zuhaili mendefinisikan perwalian yang bermaksud kuasa yang membolehkan seseorang untuk melakukan aqad atau membelanjakan harta tanpa keizinan orang lain. ${ }^{2}$

(b) Menurut al-Sayyid Sabiq, perwalian bermaksud suatu hak menurut Syarak yang berkuasa melaksanakan perintah atas orang lain dengan paksa. ${ }^{3}$

Fuad Ifram al-Bustani (1977 M), al-Munjid al-Tullab, Cet. 11. Beirut, Lubnan: Dar al-Masyriq, hal. 941.

2 Wahbah al-Zuhaily (1985 M / 1405 H), al-Fiqh al-Islami wa Adillatuh, Juz. 7, Cet. 2, Damsyiq: Dar al-Fikr, hal. 186.

3 Al-Sayyid Sabiq (1985 M / 1405H), Fiqh al-Sunnah, Cet. 7, Jil. 2. Beirut: Dar 
(c) Menurut Badran Abu al-'Ainain Badran, ianya merupakan kuasa Syarak yang diberikan kepada wali untuk menguruskan aqad nikah dan untuk membelanjakan harta serta melaksanakan perintah tersebut. ${ }^{4}$

(d) Menurut Abdul Karim Adan, perwalian ialah kekuasaan secara Syarak terhadap diri dan harta mengikut turutan perlaksanaan kedua-duanya. ${ }^{5}$

(e) Menurut Muhammad Muhyiddin Abdul Hamid, perwalian bermaksud orang yang berhak dan berkuasa untuk melakukan hukuman bagi sesiapa yang berada di bawah jagaannya menurut Syarak sama ada dengan keizinan atau paksaan. ${ }^{6}$

(f) Muhammad Salam Madkur mengatakan bahawa perwalian ialah kekuasaan yang diberikan oleh Syarak untuk membolehkan orang tersebut mengadakan akad ke atas diri dan harta untuk melaksanakan kedua-duanya menurut Syarak. $^{7}$

Melalui definisi-definisi yang diberikan ini dapat disimpulkan bahawa, "al-wilayah' merupakan suatu bentuk kuasa yang ada pada seseorang terhadap orang lain yang berada di bawah tanggungannya sama ada melibatkan harta atau diri. Dalam konteks pernikahan, ianya dapatlah disimpulkan dengan merujuk kuasa yang ada pada seseorang lelaki untuk menikahkan seseorang perempuan yang berada di bawah tanggungannya.

\section{DALIL KEPERLUAN KEPADA WALI DALAM PERNIKAHAN}

Keperluan kepada wali dalam melaksanakan sesuatu pernikahan berasaskan dalil-dalil syarak meliputi al-Quran dan al-Sunnah. Dalam surah al-Baqarah, Allah SWT berfirman yang bermaksud;

al-Kitab al-'Arabi, hal. 125.

4 Badran Abu al-`Aynayn Badran (1985 M / 1389 H), al-Ziwaj wa al-Talaq fi alIslam. Al-Iskandariah: Muassasah Syabab al-Jami’ah, hal. 134.

5 Abdul Karim Zaydan (Dr.) (1969 M / 1389 H), al-Madkhal li Dirasat al-Syariah al-Islamiyyah, Cet. 4, Matba'ah al-'Ani, hal. 334.

6 Muhammad Muhyiddin Abdul Hamid (1966 M / 1386 H), al-Ahwal al-Sakhsiyyah fi al-Syariah al- Islamiyyah. Mesir: Matba'ah al-Sa'adah, hal. 71-72.

7 Muhammad Salam Madkur (1955 M), al-Fiqh al-Islami, Cet. 2. Maktabah 'Abdullah Wahab, hal. 497. 
"Dan apabila kamu menceraikan isteri-isteri kamu, lalu habis 'iddah mereka, makajanganlah kamu (wahai wali-wali nikah) menahan mereka daripada berkahwin semula dengan (bekas) suami mereka apabila mereka berdua (lelaki dan wanita itu) bersetuju sesama sendiri dengan cara yang baik (yang dibenarkan oleh Syarak)."

(Surah al-Baqarah: Ayat 232)

Menurut Abu Bakar Muhammad dalam kitabnya Ahkam al-Quran, rangkai kata yang bererti "janganlah kamu (wahai wali-wali nikah) menahan mereka" dalam ayat di atas bermaksud larangan. Iaitu Allah SWT melarang wali kepada perempuan itu daripada menegahnya berkahwin dengan bekas suaminya. Ayat ini juga menjelaskan bahawa seseorang perempuan itu tidak berhak menikahkan dirinya sendiri, tetapi menjadi hak walinya. Sekiranya wali itu tidak diperlukan untuk menikahkan seseorang perempuan, nescaya tiadalah larangan ini. $^{8}$

Dalam kitab Fi Zilal al-Quran, Sayyid Qutb menjelaskan penurunan ayat ini berkaitan kisah Ma'qal bin Yasar yang menceritakan bahawa ayat ini diturunkan berkenaan dengan dirinya.

Katanya: "Aku menikahkan salah seorang saudara perempuanku dengan seorang lelaki, tetapi kemudiannya diceraikannya. Ketika iddahnya habis, ia datang lagi meminangnya." Maka aku jawab : Dulu kamu aku jodohkan, aku nikahkan dan aku walikan, tetapi kemudian kamu ceraikannya. Kini kamu datang untuk meminangnya lagi. Demi Allah! Kamu tidak dapat kembali lagi kepadanya untuk selama-lamanya. Lelaki ini orangnya biasa saja. Tetapi bekas isterinya itu ingin kembali kepadanya. Lalu Allah SWT menurunkan ayat ini." Kemudian aku berkata: "Sekarang aku menerimanya wahai Rasulullah, dengan ucapannya: maka aku nikahkan saudaraku itu kepadanya." 9

8 Abu Bakar Muhammad bin 'Abdullah (t.t.), Ahkam al-Qur'an. Beirut, Lubnan: Dar al-Kutub al-'Alamiyyah, hal. 273.

9 Sayyid Qutb (1971M / 1391H), Fi Zilal al-Quran, Jil. 1, Cet. 7. Beirut, Lubnan: Dar al-Ihya' al-Turath al-'Arabi, hal. 370. 
Al-Imam al-Hafidz Ibn Hajar al-'Asqalani dalam kitab Fath alBari berkata, sebab turunnya ayat ini yang paling tepat adalah kerana riwayat ini dan sekali gus merupakan alasan yang kuat tentang hukum wali dalam pernikahan. Jika seseorang wali itu tidak diperlukan, mengapakah disebutkan larangan dalam ayat di atas. Sekiranya perempuan boleh mengahwinkan dirinya sendiri, tentu ia tidak perlu kepada saudara lelakinya itu. ${ }^{10}$

Selain itu, keperluan kepada wali dalam pernikahan ini juga boleh didasarkan kepada beberapa buah hadis. Antara lain Rasulullahlah SAW bersabda yang bermaksud: ${ }^{11}$

\section{Daripada 'Aisyah (r.a.), daripada Nabi SAW sabdanya: "Tidak sah nikah, melainkan dengan berwali”.}

Perkataan "la" yang bererti "tidak" pada hadis ini bermaksud tidak sah yang merupakan erti terdekat dalam hal ini. Pernikahan tanpa wali adalah batal. Ini dijelaskan lagi dalam satu hadis yang diriwayatkan oleh 'Aisyah (r.a.) yang bermaksud: ${ }^{12}$

\section{Daripada 'Aisyah (r.a.), daripada Nabi SAW sabdanya: "Mana-mana perempuan yang berkahwin tanpa izin walinya maka nikahnya adalah batal (Nabi SAW mengulangi tiga kali) dan jika ia menyetubuhinya maka, hendaklah dibayar mahar. Jika mereka (wali) bertikai maka sultan menjadi wali sesiapa yang tidak ada walinya."}

Berdasarkan nas-nas di atas, dapat disimpulkan bahawa keperluan kepada wali itu merupakan syarat dan akan menentukan keesahan sesuatu pernikahan sebagaimana yang disyariatkan dalam Islam.

10 Ibn Hajar al-'Aswalani (1959M), Fath al-Bari bi Syarh al-Bukhari. Kaherah, Mesir: al-Matba'ah al-Salafiah wa Maktabatuha.

11 Abu 'Isa Muhammad bin 'Isa bin Surah al-Tirmidhi (1976 M / 1396 H), al-Jami' al-Sahih-Sunan al-Tirmidhi, Juz. 3. Mesir: Syarikat Maktabah wa Matba'ah Mustafa al-Babi al-Halabi wa Auladihi, hal. 398.

12 Ibid. hal. 398-399. 


\section{Syarat-syarat Wali}

Sebelum seseorang itu layak untuk bertindak sebagai wali dalam sesuatu pernikahan, ia mestilah memenuhi beberapa syarat yang digariskan oleh Syarak. Syarat tersebut iaitu:

1. Baligh - Wali itu mestilah seorang yang baligh. ${ }^{13}$ Seseorang kanak-kanak yang telah atau belum mumayyiz tidak sah menjadi wali sehinggalah ia baligh. ${ }^{14} \mathrm{Hal}$ ini kerana ia tidak mempunyai kuasa ke atas dirinya sendiri apatah lagi ke atas orang lain.

2. Berakal - Wali itu mestilah seorang yang berakal, waras, dan tidak rosak fikirannya seperti bodoh atau safih (orang yang ditahan hartanya disebabkan sifat dungu atau bodoh). ${ }^{15}$ Golongan ini tidak sah menjadi wali disebabkan mereka hilang kelayakan mewalikan diri sendiri dan orang lain. Namun, ada pendapat mengatakan, jika gilanya tidak berterusan, maka semasa siuman ia boleh menjadi wali kepada orang lain. ${ }^{16}$

3. Merdeka ${ }^{17}$ - Seseorang hamba tidak berkuasa untuk mewalikan sesiapa pun kerana apabila ia tidak berkuasa untuk mengatur dirinya, maka tentulah ia tidak berkuasa terhadap orang lain.

4. Islam ${ }^{18}$ - Disyariatkan bahawa antara wali dengan orang yang diwalikannya mestilah sama agamanya iaitu Islam. ${ }^{19}$ Orang kafir tidak sah menjadi wali. Al-Quran telah menjelaskan hal ini dalam firman Allah SWT yang bermaksud:

\footnotetext{
13 Al-Sheikh al-Imam al-'Allamah Muwaffaq al-Din bin Muhammad 'Abdullah bin Ahmad bin Mahmud bin Qudamah, op cit. hal. 356.

14 Muhammad 'Uqlah (Dr.) (1983 M / 1403 H), Nizam al-Usrah fi al-Islam, Juz. 1. 'Amman: Matba'ah al-Syarq wa Maktabatiha, hal. 282.

15 Abu Ishaq Ibrahim bin ali bin Yusuf al-Fairuzabadi al-Shirazi (1959M/1379H), al-Muhazzab fi al-Imam al-Syafi'e, Juz. 2, Cet. 2. Mesir: Syarikat Maktabah Mustafa al-Babi al-Halabi wa Auladihi, hal. 37.

16 Muhammad Najib al-Muti'iy (t.t), al-Majmu' Syarh al-Muhazzab, Juz. 15. Kaherah, Mesir: Matba'ah al-Imam, hal. 316.

17 Al-Sheikh al-Imam al-'Allamah Muwaffaq al-Din bin Muhammad 'Abdullah bin Ahmad bin Mahmud bin Qudamah (1392H/1972M), op. cit. hal. 356.

18 Ibid.

19 Wahbah al-Zuhaily, op cit. hal. 196.
} 


\section{"Dan Allah tidak sekali-kali akan memberijalan kepada orang kafir (untuk mencapai kemenangan mengatasi) orang beriman."}

(Surah al-Nisa': Ayat 141)

Tidak sah perwalian terhadap perempuan yang hendak bernikah itu jika perempuan itu seorang Islam sebaliknya walinya seorang kafir. Begitu juga halnya wali yang Islam tidak mempunyai kuasa perwalian ke atas perempuan yang kafir. Lelaki murtad pula tidak boleh mewalikan secara mutlak sama ada ke atas perempuan Islam, perempuan yang murtad atau selainnya. ${ }^{20}$ Perkara ini kerana hubungan antara mereka terputus sama sekali. ${ }^{21}$ Ini bertepatan dengan firman Allah SWT yang bermaksud:

"Dan orang yang beriman itu, lelaki perempuan, setengahnya menjadi penolong dan pelindung bagi setengahnya yang lain."

(Surah al-Taubah : Ayat 71)

Keperluan persamaan agama ini untuk kemaslahatan umat Islam dan untuk memperlihatkan kepada umum, bahawa agama Islam adalah lebih tinggi kedudukannya daripada agama lain serta memperlihatkan ketinggian kedudukan orang Islam berbanding orang kafir.

5. Adil-Wali itu hendaklah seorang yang adil. ${ }^{22}$ Kuasa perwalian akan terhalang disebabkan oleh kefasikan. Adil di sini ialah memegang dengan bersungguh-sungguh ajaran Islam dengan menunaikan segala kewajipan agama dan meninggalkan daripada melakukan dosa-dosa besar seperti berzina dan minum arak serta tidak berterusan dalam melakukan dosadosa kecil. ${ }^{23}$

Menurut al-Sayyid Sabiq, ${ }^{24}$ wali itu tidak disyaratkan berlaku adil. Orang fasiq masih berkemampuan

Ibid.

Abu Ishaq Ibrahim bin ali bin Yusuf al-Fairuzabadi al-Shirazi, op cit, hal. 37.

Al-Sheikh al-Imam al-'Allamah Muwaffaq al-Din bin Muhammad 'Abdullah bin Ahmad bin Mahmud bin Qudamah, op cit, hal. 356.

23 Ibid. hal. 197.

24 Al-Sayyid Sabiq, op. cit. hal. 125. 
menikahkan seseorang perempuan kecuali kefasikan yang keterlaluan dan tidak menenteramkan jiwa orang yang diuruskannya. Oleh sebab itu, haknya daripada menjadi wali hilang. Menurut mazhab Shafi'i dan Hanbali yang paling jelas (arjih), orang fasiq tidak boleh menjadi wali berdasarkan sabda Rasulullah SAW yang bermaksud:

\section{Daripada Ibnu Abbas (r.a.) ia berkata: Bersabda Rasulullah SAW "Tidak sah nikah kecuali dengan wali yang mursyid atau dengan sultan".}

Menurut Imam Syafie, maksud "mursyid" dalam hadis di atas ialah adil. ${ }^{25}$ Menurut Imam Abi Zakaria bin Yahya, ${ }^{26}$ sekiranya seseorang yang fasiq itu bertaubat, ia boleh menjadi wali ketika itu. Ini diqiaskan kepada penerimaan orang fasiq sebagai saksi apabila ia bertaubat dan haknya dikembalikan. Ini berbeza dengan pendapat Jumhur Fuqaha Syaf'eyyah yang menyatakan bahawa kefasikan akan menyebabkan kuasa perwalian berpindah kepada wali ab'ad.

6. Lelaki - Seseorang wali itu mestilah seorang lelaki. ${ }^{27}$ Orang perempuan tidak sah menjadi wali dalam apa jua keadaan sekalipun. Hal ini disebabkan beberapa kelainan yang ada pada kaum lelaki sebagaimana firman Allah SWT:

Maksudnya:"Kaum lelaki itu ialah pemimpin dan pengawal yang bertanggungjawab terhadap kaum perempuan, oleh sebab Allah SWT telah melebihkan orang lelaki (dengan beberapa keistimewaan) atas orang perempuan, dan juga kerana orang lelaki telah membelanjakan (memberikan nafkah) sebahagian daripada harta mereka."

(Surah al-Nisa': Ayat 34)

Pelantikan kaum lelaki dengan diberi kuasa ke atas kaum perempuan termasuk isteri dan anak-anak di

Al-Sheikh Muhammad al-Syarbini al-Khatib (1958M/1377), Mughni al-Muhtaj ila Ma'rifati Ma'ani Alfadz al-Minhaj, Juz 3. Mesir : Syarikat Maktabah wa Matba'ah Mustafa al-Babi al-Halabi wa Auladihi, hal 157.

26 Al-Imam Abu Zakaria Yahya bin Syaraf al-Nawawi al-Damsyiqi (t.t), Raudatu al-Talibin, Juz. 5. Beirut, Lubnan : Dar al-Kitab al-'Alamiyyah, hal. 410-411.

27 Al-Sheikh al-Imam al-'Allamah Muwaffaq al-Din bin Muhammad 'Abdullah bin Ahmad bin Mahmud bin Qudamah, op cit. hal. 356. 
samping dirinya pula, bertujuan menyelamatkan keadaan dan juga bertujuan untuk ditaati oleh kaum perempuan. Ini dikuatkan lagi dengan firman Allah SWT dalam surah al-Baqarah, ayat 232 (sebagaimana dijelaskan sebelum ini) bahawa pernikahan mestilah dilakukan oleh orang lelaki iaitu walinya. Jika tidak, maka tiadalah tujuan penegahan wali dalam ayat ini. ${ }^{28}$

Juga berdasarkan satu hadis yang diriwayatkan oleh Ibn Majah:

Maksudnya: Daripada Abu Hurairah (r.a.) katanya: Sabda Rasulullah SAW: "Seorang perempuan tidak boleh mengahwinkan perempuan yang lain dan tidak boleh perempuan mengahwinkan dirinya sendiri."

7. Wali tidak berada dalam ihram haji atau umrah ${ }^{29}$ - Orang yang berada dalam ihram haji dan umrah tidak sah menjadi wali. Rasulullah SAW bersabda: ${ }^{30}$

\section{Maksudnya: Daripada 'Uthman bin Affan bahawa Rasulullah SAW bersabda: "Tidak boleh menikahkan orang yang belum berada dalam ihram, tidak boleh bernikah dan tidak meminang."}

Dapat disimpulkan di sini, seseorang wali itu mestilah mempunyai syarat-syaratnya dan sekiranya tidak mencukupi seperti berlakunya seseorang wali itu gila, kafir dan sebagainya, maka ia itu tidak berhak ke atas pernikahan tersebut. Kuasa perwalian akan berpindah kepada wali yang selepasnya berdasarkan susunan wali dalam pernikahan. ${ }^{31}$

\section{PENSABITAN PERWALIAN}

Pensabitan perwalian dalam sesuatu pernikahan berdasarkan salah satu daripada sebab berikut:

\footnotetext{
28 Abu Bakar Muhammad bin 'Abdullah, op cit. hal. 273.

29 Syamsuddin Muhammad bin Abi al-' Abbas Ahmad bin Hamzah ibi Syihabuddin al-Ramli (1967M/1387H), Nihayat al-Muhtaj ila Syarh al-Minhaj, Cet. Terakhir, Juz 6. Mesir : Syarikat Maktabah wa Matba'ah Mustafa al-Babi al-Halabi wa Auladihi, hal 241.

30 Muhyiddin Abu Zakariya Yahya bin Syaraf al-Nawawi (t.t), Sahih Muslim bi Syarh al-Nawawi, Juz. 9. Beirut : Dar al-Ma'rifah, hal. 194.

31 Muhammad Najib al-Muti'iy, op cit, hal. 317.
} 
1. Pemilikan ${ }^{32}$ - iaitu sabit melalui perhambaan antara hamba dengan tuannya. Hanya tuannya sahaja yang berhak menikahkannya, sama ada hamba itu masih kecil atau besar dan sempurna akal atau tidak. Hal ini kerana hamba itu ialah hak tuannya sahaja. Tuannya itu mestilah berakil baligh. Tuan yang gila, bodoh atau masih kanak-kanak tidak boleh mewalikannya.

2. Kekeluargaan ${ }^{33}$ - iaitu hubungan yang wujud antara keluarga seperti ayah, datuk, saudara lelaki dan bapa saudara. Hubungan kekeluargaan ini memberi kuasa perwalian sepenuhnya ke atas "maula 'alaihi" dalam urusan pernikahan. Maksud "maula "alaihi" ialah orang yang berada di bawah kuasa walinya sama ada hubungan antara mereka itu jauh atau pun dekat. ${ }^{34}$

3. Pembebasan ${ }^{35}$ - iaitu hubungan yang wujud antara pembebas dan hambanya apabila hamba itu dibebaskan atau dimerdekakannya, maka ia berhak mewalikan hamba tersebut. Dalam hal ini wali itu mestilah akil baligh dan merdeka. ${ }^{36}$

4. Pemerintahan ${ }^{37}$ - ini perwalian Sultan atau naibnya seperti kadi. Hubungan yang wujud adalah antara pemimpin dengan rakyatnya. Sultan menjadi wali kepada orang yang tidak ada walinya. Pemerintah itu mestilah bersifat adil. ${ }^{38}$ Sultan boleh melantik naibnya sebagai wali hakim sejajar dengan sabda Nabi SAW:

Maksudnya; "Maka Sultan menjadi wali bagi mereka yang tidak ada wali."

\section{KLASIFIKASI WALI}

Secara umumnya, wali itu boleh dibahagikan kepada dua bahagian iaitu:

\footnotetext{
Muhammad Muhyiddin Abdul Hamid, op cit. hal. 71.

33 Muhammad 'Uqlah (1983 M / 1403 H), Nizam al-Usrah fi al-Islam, Juz. 1. 'Amman : Matba'ah al-Syarq wa Maktabatiha, hal. 284.

34 Wahbah al-Zuhaily, op cit. hal. 196.

35 Badran Abu al-`Aynayn Badran (1985 M / 1389 H), al-Ziwaj wa al-Talaq fi alIslam. Al-Iskandariah: Muassasah Syabab al-Jami’ah, hal. 143.

36 Wahbah al-Zuhaily, hal. 188.

37 Muhammad 'Uqlah hal. 284.

38 Ibid.
} 
1. al-Qasirah ${ }^{39}$

iaitu kuasa seseorang untuk menikahkan dirinya sendiri. Fuqaha bersependapat bahawa ianya diperuntukkan kepada lelaki yang akil baligh dan boleh membuat keputusan sendiri dalam hal pernikahan tanpa campur tangan orang lain.

2. al-Muta'adiyyah ${ }^{40}$

iaitu kuasa seseorang untuk menikahkan orang lain. Fuqaha tidak sependapat tentang perempuan yang akil baligh (telah dibincangkan sebelum ini).

Wali al-Muta'addiyyah boleh dibahagikan kepada beberapa bahagian lain:

1. Wali al-Muta'addiyyah dari sudut orang yang berhak mewalikannya; ${ }^{41}$

(a) al-Asliyyah - iaitu perwalian yang disabitkan dari mula lagi dan tidak memerlukan kepada bantuan orang lain seperti perwalian bapa dan datuk ianya sabit kerana kebapaan.

(b) al-Niyabiyyah - iaitu perwalian yang diambil daripada orang lain selain daripada bapa dan datuk. Seperti perwalian bapa saudara dan sebagainya.

2. Wali al-Muta'addiyyah dari sudut orang yang berada di bawah kuasa walinya; ${ }^{42}$

(a) al-Ijbar - iaitu kuasa penuh untuk melakukan akad pernikahan ke atas perempuan yang masih gadis di bawah umur secara paksa tanpa keizinan perempuan itu terlebih dahulu dengan lelaki yang sekufu dengannya. Kuasa ini terletak kepada bapa dan datuk (bapa dari bapa).

(b) al-Ikhtiyar - iaitu kuasa penuh melakukan akad perkahwinan tetapi tidak mempunyai kuasa mutlak untuk memaksanya berkahwin. Kuasa ini terletak kepada wali nasab selain daripada bapa dan datuk.

\footnotetext{
39 Imam Muhammad Abu Zahrah (1957M/1377H), Ahwal al-Sakhsiyyah, Dar alFikr al-Arabi, hal. 107.

40 Ibid.

41 Badran Abu al-'Aynayn Badran (1985 M / 1389 H), al-Ziwaj wa al-Talaq fi alIslam. Al-Iskandariah: Muassasah Syabab al-Jami’ah, hal. 143.

42 Imam Muhammad Abu Zahrah, hal. 108.
} 
3. Perwalian al-Muta'addiyyah dari sudut kuasa;

(a) al-'Ammah - iaitu pensabitannya kepada ketua negara dan pelaksanaannya secara perundangan dan bukannya peribadi dan terletak pada pemerintah

(b) al-Khassah - iaitu pensabitannya kepada orang perseorangan dan perlaksanaannya secara peribadi dan bukannya secara perundangan. Terletak di tangan para wali berdasarkan turutan wali nasab.

\section{SUSUNAN DAN PERPINDAHAN KUASA WALI}

Merujuk kepada mazhab Hanafi, turutan wali adalah seperti berikut iaitu anak dan cucu hingga ke bawah, bapa dan datuk hingga ke atas, saudara lelaki seibu sebapa dan saudara lelaki sebapa dan anak-anak lelaki kedua-duanya hingga ke bawah, bapa saudara seibu sebapa, bapa saudara sebapa dan anak-anak daripada kedua-duanya, bapa saudara kepada bapa seibu sebapa, bapa saudara kepada bapa sebapa dan anak daripada kedua-duanya, bapa saudara kepada datuk seibu sebapa, bapa saudara kepada datuk sebapa dan anak daripada keduaduanya, para 'asobah sebelah ibu, al-mu'tiq, para 'asobah senasab yang lain dan sultan. ${ }^{43}$

Dalam mazhab Maliki pula turutannya adalah seperti berikut iaitu anak lelaki dan cucu lelaki hingga ke bawah, bapa saudara lelaki seibu sebapa, saudara lelaki sebapa, anak saudara lelaki sebapa, datuk, bapa saudara, kemudian anak lelaki bapa saudara dan didahulukan seibu sebapa, bapa kepada datuk, bapa saudara sebapa dan anaknya, bapa saudara datuk dan anak lelakinya, al-mu'tiq, hakim atau kadi, akhirnya semua lelaki Muslim yang layak menjadi wali iaitu sebagai wali tahkim atau al-muhakkam. ${ }^{44}$

Mengikut mazhab Syafie, ${ }^{45}$ susunan wali adalah seperti berikut; bapa, datuk, saudara lelaki seibu sebapa, saudara lelaki sebapa, anak

43 Al-Sheikh 'Abdul Rahman al-Jaziri (t.t), Ahkam al-Quran. Beirut, Lubnan : Dar al-Kutub al-'Alamiyyah, hal 47. Lihat juga Wahbah al-Zuhaily, op cit. hal. 199.

44 Al-Sheikh 'Abdul Rahman al-Jaziri, hal 48. Lihat juga Wahbah al-Zuhaily, hal. 201.

45 Abu Ishaq Ibrahim bin ali bin Yusuf al-Fairuzabadi al-Shirazi, op cit. hal. 37. Al-Sheikh Muhammad al-Syarbini al-Khatib, op cit, hal 151-152. 
saudara lelaki daripada saudara lelaki seibu sebapa, anak saudara lelaki daripada saudara lelaki sebapa, bapa saudara sebelah bapa seibu sebapa, bapa saudara sebelah bapa sebapa, anak lelaki bapa saudara sebelah bapa seibu sebapa, bapa saudara bapa seibu sebapa, bapa saudara bapa sebapa, anak lelaki bapa saudara bapa seibu sebapa, anak saudara lelaki bapa saudara bapa sebapa, al-mu'tiq, sekalian 'asobah kepadanya dan akhirnya sultan (wali hakim).

Menurut mazhab Hanbali, turutannya ialah bapa, datuk hingga ke atas, anak lelaki dan cucu lelakinya hingga ke bawah, saudara lelaki seibu sebapa, saudara lelaki sebapa, anak-anak lelaki saudara perempuan, bapa saudara dan anak-anaknya, bapa saudara kepada bapa, al-mu'tiq dan 'asobah daripadanya dan akhir sekali sultan. ${ }^{46}$

Berdasarkan susunan ini, dapat dilihat kuasa perwalian yang pertama sekali ialah wali aqrab iaitu bapa atau datuk. Sekiranya mereka masih ada, hak menikahkan perempuan itu tidak akan boleh dipindahkan kepada wali ab 'ad (selain daripada wali bapa, datuk dan sultan). Ketiadaan wali aqrab adalah jika berlaku wali itu mati atau hak kuasa wali aqrab telah hilang menurut hukum syarak seperti wali itu menjadi hamba abdi, ghaib, bodoh (kurang akal), kafir atau sedang dalam ihram mengerjakan haji atau umrah. Dalam hal ini, kuasa perwalian akan berpindah kepada wali $a b^{6} a d .{ }^{47}$

Selain itu, dapat dilihat juga kuasa perwalian itu akan berpindah daripada wali nasab kepada wali hakim. Badran Abu al-Ainain Badran menyatakan bahawa wali hakim ialah pemerintah yang mempunyai kuasa melaksanakan segala tindakan ke atas rakyatnya sama ada mereka setuju atau tidak selagi mana tindakan itu adalah untuk kebaikan mereka yang meliputi kuasa hakim atau naibnya. ${ }^{48}$ Ahmad al-Hasri pula mendefinisikan wali hakim sebagai sultan atau hakim atau sesiapa sahaja yang dilantik dan diberikan kuasa kepadanya untuk menjadi wali ketika ketiadaan wali khas dengan sebab kekeluargaan umpamanya. ${ }^{49}$

46 Al-Sheikh al-Imam al-'Allamah Muwaffaq al-Din bin Muhammad 'Abdullah bin Ahmad bin Mahmud bin Qudamah, op cit. hal. 346-350.

47 H. Idris Ahmad S.H. (1995), Fiqh Syafii, Jil. II, Cet. Ketiga. Kuala Lumpur : Pustaka Antara Sdn Bhd. Hal. 240 - 242.

48 Badran Abu al-'Aynayn Badran, op cit. hal. 141.

49 Ahmad al-Hasri (1987M/1406H), al-Nikah wa al-Qadaya al-Muta'alliqat bihi, Cet. 1. Beirut, Lubnan: Dar Ibn Zaidun, hal. 501. 
Kuasa perwalian daripada wali nasab akan berpindah kepada wali hakim dalam keadaan berikut:

(a) Ketiadaan wali nasab atau luput wali - Ini berlaku apabila perempuan yang hendak berkahwin itu tidak mempunyai walinya yang sah untuk menikahkannya. ${ }^{50}$ Ini berlaku dalam keadaan pernikahan saudara baru ${ }^{51}$ dan juga perempuan itu tidak dinasabkan kepada bapanya. ${ }^{52}$

(b) Wali enggan ('Adhal) - iaitu menghalang seseorang perempuan daripada bernikah dengan lelaki yang sekufu dengannya apabila diminta menikahkannya. ${ }^{53}$ Fuqaha bersependapat bahawa jika berlaku keengganan wali aqrab untuk menikahkan perempuan itu, kuasa pernikahan akan berpindah daripadanya kepada wali hakim. ${ }^{54}$

(c) Wali mafqud - iaitu wali yang hilang dan terputus hubungan daripadanya serta tidak diketahui di mana ia berada sama ada masih hidup atau telah meninggal dunia. ${ }^{55}$

(d) Wali ghaib. ${ }^{56}$

(e) Waliaqrab dipenjarakan atau ditahan-iaitu pemenjaraan atau penahanan ke atas wali aqrab kerana melakukan perbuatan yang menyalahi undang-undang atau ditawan oleh musuh, sama ada di dalam atau di luar negeri, tetapi tidak dibenarkan bercampur gaul dengan masyarakat. Hanya menurut mazhab

50 Muhammad Najib al-Muti'iy, op cit, hal. 319.

51 Wahbah al-Zuhaily, op cit, hal. 196.

52 H. Idris Ahmad S.H., op cit, hal. 360 - 361.

53 Al-Sheikh al-Imam al-'Allamah Muwaffaq al-Din bin Muhammad 'Abdullah bin Ahmad bin Mahmud bin Qudamah, op cit, hal. 327. Lihat juga Muhammad Muhyiddin Abdul Hamid, op cit. hal. 89. Lihat juga Wahbah al-Zuhaily, op cit, hal. 215.

54 Muhammad Amin al-Syahir (Ibn 'Abidin) (1966M / 1387H), Hasiyat Rad alMuhtar, Cet. 2, Jil. 3. Damsyiq : Dar al-Fikr, hal. 82. Lihat juga Wahbah alZuhaily, op cit, hal. 217. Lihat juga Al-Imam Abi 'Abdillah Muhammad bin Idris al-Syafi'e, op cit, hal. 368

55 Syamsuddin Muhammad bin Abu al-'Abbas Ahmad bin Hamzah bin Syihabuddin al-Ramli, op cit. hal. 234. Lihat juga Muhammad Najib al-Muti'iy, op cit. hal. 319. Lihat juga Wahbah al-Zuhaily, op cit, hal. 219. Lihat juga AlSheikh al-Imam al-'Allamah Muwaffaq al-Din bin Muhammad 'Abdullah bin Ahmad bin Mahmud bin Qudamah, op cit, hal. 370.

56 Abu Muhammad 'Ali bin Ahmad bin Sa'id bin Hazm, op cit, hal. 458. Lihat juga Muhammad Najib al-Muti'iy, op cit, hal. 320. Lihat juga Wahbah al-Zuhaily, op cit. hal. 218-219. Lihat juga Al-Imam Abu Zakaria Yahya bin Syaraf alNawawi al-Damsyiqi, op cit, hal 414. 
Syafi'e, kuasa akan berpindah kepada wali hakim dalam hal ini iaitu jika sukar untuk menemuinya dan dihalang untuk melakukan akad pernikahan. ${ }^{57}$

(f) Wali sendiri hendak bernikah - ini berlaku apabila wali sendiri hendak bernikah dengan perempuan yang berada di bawah kuasa perwaliannya yang tidak mengharamkan mereka bernikah.

(g) Wali berada dalam Ihram Haji atau Umrah. ${ }^{58}$

Dalam keadaan di atas, jika berlaku, kuasa wali aqrab akan berpindah kepada wali sejajar dengan sabda Baginda SAW yang bermaksud;

Daripada 'Aisyah (r.a.), daripada Nabi SAW sabdanya: "Mana-mana perempuan yang berkahwin tanpa izin walinya maka nikahnya adalah batal (Nabi s.a.w. mengulangi tiga kali) dan jika ia menyetubuhinya maka, hendaklah dibayar mahar. Jika mereka (wali) bertikai maka sultan menjadi wali sesiapa yang tidak ada walinya."

\section{KEPERLUAN KEPADA WALI DALAM PERNIKAHAN SESEORANG WANITA BERSTATUS ANAK DARA MENURUT PENDAPAT FUQAHA' FIQH}

Fuqaha' berbeza pendapat dalam menentukan sama ada seseorang wali itu diperlukan atau tidak dalam sesuatu pernikahan melibatkan wanita berstatus anak dara. Persoalan yang timbul iaitu sama ada seseorang perempuan itu boleh menikahkan dirinya sendiri atau pun walinya sahaja yang layak untuk menikahkannya.

Fuqaha' Yang Berpandangan Perlu Keizinan Wali Menurut Imam Malik dalam al-Mudawwanat al-Kubra, tidak sah sesuatu pernikahan itu sekiranya tidak ada wali. Beliau merujuk kepada hadis riwayat "Aisyah (r.a.) dan juga hadis Rasulullah SAW yang bermaksud; ${ }^{59}$

\footnotetext{
57 Al-Sheikh Muhammad al-Syarbini al-Khatib, op cit. hal 157.

58 Ibid.

59 Al-Imam Malik bin Anas (t.t), al-Mudawwanat al-Kubra, Jil. 2. Beirut, Lubnan : Dar Sadir, hal. 125-126.
} 
"Tidak halal (sah) nikah melainkan dengan wali, mahar dan dua orang saksi yang adil."

Sementara itu, Imam Syafi'e dalam al-Umm bersependapat dengan Imam Malik. Menurut beliau, sekiranya seseorang perempuan itu menikahkan dirinya sendiri, maka pernikahan itu adalah batal. ${ }^{60}$ Imam Syafi'e dalam hal ini bersandarkan firman Allah SWT dalam surah al-Baqarah yang bermaksud;

"Dan apabila kamu menceraikan isteri-isteri kamu, lalu habis 'iddah mereka, maka janganlah maka janganlah kamu (wahai wali-wali nikah) menahan mereka daripada berkahwin semula dengan (bekas) suami mereka apabila mereka berdua (lelaki dan wanita itu) bersetuju sesama sendiri dengan cara yang baik (yang dibenarkan oleh Syarak)."

(Surah al-Baqarah: Ayat 232)

Selain itu, beliau juga merujuk hadis riwayat 'Aisyah (r.a.) bahawa Rasulullah SAW bersabda yang bermaksud:

\section{"Mana-mana perempuan yang berkahwin tanpa izin walinya maka nikahnya adalah batal (Nabi SAW mengulangi tiga kali) dan jika ia menyetubuhinya maka, hendaklah dibayar mahar. Jika mereka (wali) bertikai maka sultan menjadi}

60 Al-Imam Abi 'Abdillah Muhammad bin Idris al-Syafi'e (t.t.), al-Umm, Juz. 5, Cet. 2. Beirut, Lubnan: Dar al-Ma'arif, hal. 13. Namun begitu, situasinya adalah berbeza dalam kes perempuan thayyib (janda atau sudah bukan dara) di mana menurut mazhab Syafi'e, keizinan mereka diperlukan terlebih dahulu. Ini dapat dilihat dalam kitab Al-Mughni al-Muhtaj dinyatakan, "Dan seorang wali tidak boleh mengahwinkan perempuan yang thayyib (janda atau sudah bukan dara) yang telah baligh walaupun daranya kembali semula, sebagaimana yang telah dijelaskan oleh Abu Khalaf at-Tobari dalam kitab Syarh al-Miftah, melainkan dengan mendapat keizinan daripada perempuan thayyib itu. Perkara ini berdasarkan satu hadis yang diriwayatkan oleh ad-Daruqutni terdahulu dan satu hadis "janganlah kamu kahwinkan perempuan....." diriwayatkan oleh alTirmizi. Beliau menyatakan hadis tersebut adalah hadis hassan sohih. Perlu kepada izin perempuan thayyib adalah kerana perempuan thayyib mengerti maksud pernikahan, kerana itu tidak boleh dipaksa untuk akad nikah, berbeza dengan perempuan yang masih dara." Lihat kes Nurul Syakira Mohd Ayub lwn Al Mohd Firdaus Mat Razi [2017] 3 LNS 24. 
wali sesiapa yang tidak ada walinya."

Berdasarkan hadis ini jelaslah bahawa pernikahan tanpa wali itu adalah batal sama sekali. ${ }^{61}$ Pendapat ini disokong juga oleh Imam Ahmad Ibn Hanbal sebagaimana dinukilkan oleh Ibnu Qudamah dalam al-Mughni. ${ }^{62}$

Syamsuddin al-Sarkhasi dalam kitab al-Mabsut menyatakan bahawa wali hanyalah disyariatkan kepada perkahwinan kanak-kanak dan orang gila sama ada lelaki atau perempuan walaupun dewasa. ${ }^{63}$

Imam Ibnu Hazm dalam kitab al-Muhalla, berpendapat bahawa tidak sah seseorang perempuan itu sama ada masih anak dara atau tidak, mengahwinkan dirinya sendiri kecuali dengan keizinan daripada walinya. ${ }^{64}$ Beliau berpegang kepada ayat al-Quran dalam surah alNur yang menurutnya perintah itu adalah ditujukan kepada para wali dan bukannya kepada kaum perempuan. Ayat itu bermaksud;

\section{"Dan kahwinkanlah orang bujang (lelaki dan perempuan) daripada kalangan kamu, dan orang salih daripada kalangan hamba kamu, lelaki dan perempuan."}

(Surah al-Nur: Ayat 32)

\section{Fuqaha' Yang Berpandangan Keizinan Wali Tidak Diperlukan}

Menurut Syamsuddin al-Sarkhasi, bagi perempuan yang baligh dan berakal sama ada gadis atau janda, maka tidak ada sesiapapun yang berhak mewalikannya, sekalipun walinya. Mereka berhak mewalikan dirinya sendiri dengan syarat lelaki itu sekufu. Sekiranya tidak sekufu, maka wali berhak menentang dan memfasakhkan pernikahan itu. ${ }^{65}$

Dalam hal ini, mazhab Hanafi berhujah berdasarkan firman Allah SWT dalam surah al-Baqarah yang bermaksud:

61 Ibid.

62 Al-Sheikh al-Imam al-'Allamah Muwaffaq al-Din bin Muhammad 'Abdullah bin Ahmad bin Mahmud bin Qudamah (1392H/1972M), al-Mughni, Juz. 7. Beirut, Lubnan: Dar al-Fikr al-'Arabi, hal. 346.

63 Syamsuddin al-Sarkhasi (1398 H / 1978 M), al-Mabsut, Juz. 15, Cet. 3. Beirut, Lubnan: Dar al-Ma'arif, hal. 10.

64 Abu Muhammad 'Ali bin Ahmad bin Sa'id bin Hazm (t.t.) al-Muhalla, Juz. 9. Kaherah: Dar al-Turath, hal. 451.

65 Ibid, hal. 10. 
“... daripada berkahwin dengan (bekas) suami mereka..."

(Surah al-Baqarah: Ayat 232)

Mereka juga berpegang kepada hadis: ${ }^{66}$

Maksudnya: "Janda berhak ke atas dirinya sendiri daripada walinya dan gadis diminta pendapatnya tentang dirinya dan keizinannya ialah diamnya."

Berdasarkan dalil-dalil inilah mazhab Hanafi berpandangan bahawa orang perempuan mempunyai kelayakan yang sempurna untuk mengurus hartanya dengan sendiri seperti jual beli, gadaian dan sebagainya. Maka, dengan sendirinya ia juga berkelayakan sepenuhnya untuk mengahwinkan dirinya sendiri. Pernikahan itu ialah hak perempuan itu sendiri untuk menentukannya.

Dilihat kepada pendapat para fuqaha Islam ini, pendapat majoriti ulama (Jumhur) adalah lebih kuat dan lebih jelas lagi bahawa seseorang perempuan itu tidak berhak untuk menikahkan dirinya sendiri walaupun ia seorang yang berakal dan baligh sebagaimana menurut pendapat Imam Abu Hanifah.

Selain perkara ini, keperluan wali itu dapat dilihat secara rasionalnya daripada beberapa aspek penting. Menurut Sayyid Sabiq, perempuan kebiasaannya dipengaruhi oleh perasaannya sehingga ia tidak pandai dalam memilih bakal suaminya. Ia juga langsung tidak boleh mengurus akadnya, tetapi hendaklah diserahkan kepada walinya agar tujuan utama dan matlamat sesuatu pernikahan itu tercapai. ${ }^{67}$ Haron Din pula berpandangan bahawa orang perempuan ialah kaum yang lemah yang sentiasa berhajat kepada layanan dan pimpinan daripada kaum lelaki bagi mengelakkan mereka daripada senang dipengaruhi dan keselamatan mereka tergugat. ${ }^{68}$

${ }_{66}$ Muhammad bin 'Ali bin Muhammad al-Syaukani (t.t), Nail al-Autar Syarh Muntaqa al-Akhbar min Ahadith Sayyid al-Akhyar, juz. 6, Cet. Terakhir. Hal. 137.

$67 \quad$ Al-Sayyid Sabiq, op. cit., hal. 127.

68 Haron Din (1997), Manusia dan Islam, Jilid 2. Kuala Lumpur, Dewan Bahasa dan Pustaka, hal. 212. 
Penulis cenderung kepada pandangan oleh majoriti Fuqaha' yang menetapkan bahawa sesuatu perkahwinan memerlukan kepada keizinan daripada wali. Selain berdasarkan kepada nas-nas Syarak yang menjadi sandaran Fuqaha', penulis juga melihat kepada rasional diperlukan keizinan wali atas landasan berikut:

(a) Keperluan kepada wali juga adalah untuk menjaga hubungan rumah tangga dan kekeluargaan antara seorang anak dengan ibu bapa atau penjaga yang berhak mewalikannya.

(b) Begitu juga kebiasaannya orang tua lebih tahu tentang kedudukan dan kesesuaian bakal suami anak perempuannya kerana dalam Islam, pergaulan antara lelaki dengan perempuan terikat dengan batasan Syarak tertentu menyebabkan mereka tidak bebas dan tidak mampu mengenali siapakah yang sesuai dengannya.

Oleh hal yang sedemikian, penulis berpandangan bahawa betapa perlunya seorang wali dalam perkahwinan seseorang perempuan masih lagi anak dara sunti dan berumur belasan tahun.

\section{KUASA WALI MUJBIR DALAM PERNIKAHAN WANITA BERSTATUS ANAK DARA}

Suatu perkarayang perluuntuk diketengahkan dalam membincangkan kuasa wali ialah berkaitan kuasa paksaan (ijbar) oleh seseorang wali dalam menikahkan seseorang perempuan. Sebagaimana dinyatakan dalam pembahagian kuasa wali sebelum ini, kategori wali almuta'addiyah itu boleh dibahagikan kepada kuasa paksaan (ijbar) yang merujuk kuasa penuh untuk melakukan akad pernikahan ke atas perempuan yang masih gadis di bawah umur secara paksa (ijbar) tanpa memerlukan keizinan seseorang perempuan itu terlebih dahulu dengan lelaki yang sekufu dengannya. Kuasa ini terletak kepada bapa dan datuk (bapa daripada bapa). ${ }^{69}$

Wali Mujbir itu merujuk wali bapa atau datuk yang mempunyai bidang kuasa untuk mengahwinkan anak atau cucu yang masih lagi

69 Imam Muhammad Abu Zahrah, hal. 108; Lihat juga al-Jaziri, 'Abd Al-Rahman., 1999, Kitab al-Fiqh 'ala al-Madhahib al-Arba' ah, Jil. 4, Kaherah: Dar al-Manar, hal. 26. 
berstatus anak dara tanpa perlu meminta izin daripada perempuan itu terlebih dahulu. Perkara ini adalah kerana bapa dan datuk lebih mengetahui maslahat anak gadis tersebut lantaran wujudnya perasaan kasih sayang atas dasar ikatan kekeluargaan antara mereka. Mustahil, bapa atau datuk akan memilih calon suami yang tidak sesuai dengan maslahat perempuan tersebut. ${ }^{70}$

Persoalannya, sejauh manakah kuasa yang ada pada wali mujbir untuk menikahkan seseorang wanita (anak atau cucu) yang masih anak dara? Apakah wali mujbir itu berkuasa mutlak tanpa sebarang syarat? Syh Noorul Madihah Syed Husin dan Tengku Fatimah Muliana Tengku Muda ${ }^{71}$ dalam penulisan mereka memetik secara jelas pandangan Imam al-Syarbini dalam kitab Mughni al-Muhtaj ila Ma 'rifah Ma 'ani Alfaz al-Minhaj, bahawa kuasa wali mujbir dalam kes pernikahan tanpa memerlukan izin bakal pengantin perempuan hanya sah apabila memenuhi beberapa syarat berikut:

a. Tidak wujud unsur permusuhan yang ketara antara wali dengan anak atau cucu perempuannya yang akan dikahwinkan;

b. Bakal pengantin lelaki yang dicalonkan oleh wali mestilah sekufu dengan bakal pengantin perempuan;

c. Calon suami merupakan seorang lelaki yang berkemampuan untuk membayar mahar kepada calon isteri.

Selain daripada tiga syarat di atas, Imam al-Syarbini menambah lagi syarat-syarat yang mengharuskan paksaan untuk menikahkannya iaitu; calon isteri mesti dibayar dengan mahar misil daripada nilai mata wang tempatan; calon suami mesti bukan daripada lelaki yang menyukarkan isteri untuk menyesuaikan diri dengannya seperti orang yang terlalu tua dan buta; dan calon isteri juga mesti dipastikan masih belum memenuhi syarat wajib haji. ${ }^{72}$

$\overline{70}$ Mustafa al-Khin, Mustafa al-Bugha dan Ali al-Sharbaji (2016). Al-Fiqh al-Manhajiy - Manhaj Figh al-Shafii, terjemahan oleh Rasyidah Adam dan Shaifudin Maulup, Jil. 4, Negeri Sembilan: Jabatan Mufti Kerajaan Negeri, hal. 137.

71 Syh Noorul Madihah Syed Husin dan Tengku Fatimah Muliana Tengku Muda, (2011), Konflik antara hak wali mujbir di bawah hukum syarak dan peruntukan had umur minimum perkahwinan. Jurnal Islam dan Masyarakat Kontemporari, Keluaran Khas, hal. 11.

72 Ibid. 
Penetapan syarat-syarat ini memperlihatkan bahawa kuasa ijbar yang ada pada wali masih dibatasi dengan landasan Syarak sebagaimana menurut mazhab Syafie. Kuasa itu akan hilang sekiranya syaratsyarat yang ditetapkan tidak dipenuhi. Hal ini penting dalam menjaga kepentingan dan maslahat bakal pengantin perempuan yang masih berstatus anak dara juga mengelakkan berlakunya penganiayaan terhadap anak gadis. Seterusnya bakal pengantin lelaki itu ialah seorang yang berkemampuan untuk menyara bakal isterinya dan juga elemen kafaah (sekufu) bagi menjamin keharmonian institusi keluarga yang akan didirikan. ${ }^{73}$

Walaupun wali mujbir mempunyai kuasa ijbar terhadap anak gadis mereka, namun adalah lebih baik sekiranya wali mujbir itu mengambil kira pandangan bakal pengantin perempuan itu terlebih dahulu. Sesuatu yang afdal dan sunat apabila meminta izin terlebih dahulu untuk mengahwinkannya. Ini secara tidak langsung sebagai tanda penghormatan dan juga menyedapkan hati bakal pengantin yang bakal mendirikan rumah tangga dengan bakal suami pilihan wali mujbir. Hal ini juga kerana anak dara kebiasaannya berasa malu untuk berterus terang dan menyatakan persetujuannya. ${ }^{74}$

Ini dilihat selari dengan sabda Rasulullah SAW yang bermaksud: "Janganlah dikahwinkan janda hingga diminta persetujuannya, dan janganlah dikahwinkan anak dara sehingga diminta izinnya". Para sahabat bertanya, "Bagaimana mengetahui keizinannya?" Sabda Rasulullah SAW; "Dia diam". Demikian juga dalam hadis yang bermaksud, daripada Ibn Abbas r.a., Nabi SAW bersabda, "Seseorang janda lebih berhak terhadap dirinya berbanding wali. Anak dara pula perlu diminta izinnya. Diam ialah tanda keizinannya". ${ }^{75}$

Bagi kes perkahwinan perempuan berstatus janda pula sebagaimana disebut sebelum ini, tidak boleh dikahwinkan oleh walinya walaupun bapanya sendiri. Janda di sini bermaksud perempuan yang telah hilang selaput daranya disebabkan berlakunya persetubuhan yang halal ataupun haram dan bukan disebabkan penyakit, terjatuh dan sebagainya. Perkahwinan hanya boleh dilakukan dengan keizinan dan kerelaannya sahaja. Ini berdasarkan kepada kedua-dua hadis di atas. $^{76}$

Ibid.

74 Mustafa al-Khin, Mustafa al-Bugha dan Ali al-Sharbaji, op cit, hal. 138.

75 Ibid, hal. 139-139.

76 Ibid, hal. 140. 
Jika dilihat kepada keperluan mendapat persetujuan daripada janda untuk menikahkannyapula, adalahkerana seseorang perempuan janda itu lebih memahami tujuan perkahwinan setelah ia mendirikan rumah tangga. Ia tidak boleh dipaksa kerana berdasarkan pengalaman yang telah dilaluinya, kebiasaannya menyebabkan ia tidak akan berasa malu untuk berterus terang sama ada bersetuju atau tidak kepada perkahwinan yang dicadangkan. Perkara ini menjadikan seseorang perempuan janda itu lebih berhak menentukan apa yang diingininya dalam mendirikan rumah tangga untuk kesekian kalinya. ${ }^{77}$

\section{KESIMPULAN}

Berdasarkan perbincangan tentang perwalian dari perspektif fiqh ini, jelas menunjukkan bahawa kewujudan wali merupakan elemen yang penting dalam menentukan keesahan sesuatu pernikahan. Keperluan keizinan atau kebenaran wali itu bergantung kepada status seseorang perempuan yang akan melangsungkan perkahwinan. Dalam kes perempuan berstatus anak dara, wali mujbir berkuasa untuk menikahkannya dengan lelaki pilihan wali mujbir. Namun begitu kuasa ijbar itu tidak bersifat mutlak; dibatasi dengan batasan Syarak bagi memastikan matlamat Syarak sesuatu perkahwinan itu akan tercapai dan memberikan maslahat kepada anak dara terbabit. Bagi seseorang perempuan berstatus janda pula, keizinan daripadanya diperlukan. Kuasa ijbar tidak boleh dikenakan terhadap mereka oleh wali. Kedua-dua situasi ini mempunyai hikmah yang tersendiri dalam usaha menjadikan pasangan suami isteri itu hidup dalam keadaan harmoni menjalani bahtera rumah tangga Islam sebagaimana yang dikehendaki oleh Syarak.

\section{RUJUKAN}

Abdul Karim Zaydan. (1969 M / 1389 H). al-Madkhal li Dirasat alSyariah al-Islamiyyah, Cet. 4, Matba'ah al-'Ani.

Abu 'Isa Muhammad bin 'Isa bin Surah al-Tirmidhi. (1976 M / 1396 H). al-Jami' al-Sahih-Sunan al-Tirmidhi, Juz. 3. Mesir: Syarikat Maktabah wa Matba'ah Mustafa al-Babi al-Halabi wa Auladihi.

77 Ibid, hal. 140-141. 
Abu Bakar Muhammad bin 'Abdullah (t.t.). Ahkam al-Quran. Beirut, Lubnan: Dar al-Kutub al-'Alamiyyah.

Abu Ishaq Ibrahim bin ali bin Yusuf al-Fairuzabadi al-Shirazi (1959M/1379H). al-Muhazzab fi al-Imam al-Syafi'e, Juz. 2, Cet. 2. Mesir: Syarikat Maktabah Mustafa al-Babi al-Halabi wa Auladihi.

Abu Muhammad 'Ali bin Ahmad bin Sa'id bin Hazm. (t.t.) alMuhalla, Juz. 9. Kaherah: Dar al-Turath.

Ahmad al-Hasri. (1987M/1406H). al-Nikah wa al-Qadaya alMuta'alliqat bihi, Cet. 1. Beirut, Lubnan: Dar Ibn Zaidun.

Al-Imam Abi 'Abdillah Muhammad bin Idris al-Syafi'e (t.t.), alUmm, Juz. 5, Cet. 2. Beirut, Lubnan: Dar al-Ma'arif.

Al-Imam Abu Zakaria Yahya bin Syaraf al-Nawawi al-Damsyiqi.

(t.t). Raudatu al-Talibin, Juz. 5. Beirut, Lubnan: Dar al-Kitab al-'Alamiyyah.

Al-Imam Malik bin Anas. (t.t). al-Mudawwanat al-Kubra, Jil. 2. Beirut, Lubnan: Dar Sadir.

Al-Sayyid Sabiq. (1985 M / 1405H). Fiqh al-Sunnah, Cet. 7, Jil. 2. Beirut: Dar al-Kitab al-'Arabi.

Al-Sheikh 'Abdul Rahman al-Jaziri. (t.t). Ahkam al-Quran. Beirut, Lubnan: Dar al-Kutub al-'Alamiyyah.

Al-Sheikh al-Imam al-'Allamah Muwaffaq al-Din bin Muhammad 'Abdullah bin Ahmad bin Mahmud bin Qudamah. (1392H/1972M). al-Mughni, Juz. 7. Beirut, Lubnan: Dar alFikr al-'Arabi.

Al-Sheikh Muhammad al-Syarbini al-Khatib. (1958 M / 1377 H). Mughni al-Muhtaj ila Ma'rifati Ma'ani Alfadz al-Minhaj, Juz 3. Mesir: Syarikat Maktabah wa Matba'ah Mustafa al-Babi al-Halabi wa Auladihi.

Badran Abu al-'Aynayn Badran. (1985 M / 1389 H). al-Ziwaj wa al-Talaq fi al-Islam. Al-Iskandariah: Muassasah Syabab alJami'ah.

Badran Abu al-'Aynayn Badran. (1985 M / 1389 H). al-Ziwaj wa al-Talaq fi al-Islam. Al-Iskandariah: Muassasah Syabab alJami'ah.

Badran Abu al-'Aynayn Badran. (1985 M / 1389 H). al-Ziwaj wa al-Talaq fi al-Islam. Al-Iskandariah: Muassasah Syabab alJami'ah.

Fuad Ifram al-Bustani. (1977 M). al-Munjid al-Tullab, Cet. 11. Beirut, Lubnan: Dar al-Masyriq.

H. Idris Ahmad S. H. (1995). Fiqh Syafii, Jil. II, Cet. Ketiga. Kuala 
Lumpur: Pustaka Antara Sdn Bhd.

Ibn Hajar al-'Aswalani. (1959 M). Fath al-Bari bi Syarh al-Bukhari. Kaherah, Mesir: al-Matba'ah al-Salafiah wa Maktabatuha.

Imam Muhammad Abu Zahrah. (1957 M / 1377 H). Ahwal alSakhsiyyah, Dar al-Fikr al-Arabi.

Muhammad 'Uqlah. (1983 M / 1403 H). Nizam al-Usrah fi al-Islam,

Juz. 1. 'Amman: Matba'ah al-Syarq wa Maktabatiha, hal. 284.

Muhammad 'Uqlah.(1983 M / 1403 H). Nizam al-Usrah fi al-Islam, Juz. 1. 'Amman: Matba'ah al-Syarq wa Maktabatiha.

Muhammad Amin al-Syahir. (Ibn 'Abidin) (1966M / 1387H). Hasiyat Rad al-Muhtar, Cet. 2, Jil. 3. Damsyiq: Dar al-Fikr.

Muhammad bin 'Ali bin Muhammad al-Syaukani. (t.t). Nail al-Autar Syarh Muntaqa al-Akhbar min Ahadith Sayyid al-Akhyar, juz. 6, Cet. Terakhir.

Muhammad Muhyiddin Abdul Hamid. (1966 M / 1386 H). al-Ahwal al-Sakhsiyyah fi al-Syariah al-Islamiyyah. Mesir : Matba'ah al-Sa'adah.

Muhammad Najib al-Muti'iy. (t.t). al-Majmu'Syarh al-Muhazzab, Juz. 15. Kaherah, Mesir: Matba'ah al-Imam.

Muhammad Salam Madkur. (1955 M). al-Figh al-Islami, Cet. 2. Maktabah 'Abdullah Wahab.

Muhyiddin Abu Zakariya Yahya bin Syaraf al-Nawawi. (t.t). Sahih Muslim bi Syarh al-Nawawi, Juz. 9. Beirut : Dar al-Ma'rifah. Mustafa al-Khin, Mustafa al-Bugha., \& Ali al-Sharbaji. (2016). Al-Fiqh al-Manhajiy - Manhaj Fiqh al-Shafii. Terjemahan oleh Rasyidah Adam dan Shaifudin Maulup, Jil. 4, Negeri Sembilan: Jabatan Mufti Kerajaan Negeri.

Sayyid Qutb. (1971M / 1391H). Fi Zilal al-Quran, Jil. 1, Cet. 7. Beirut, Lubnan: Dar al-Ihya' al-Turath al-'Arabi.

Syamsuddin al-Sarkhasi. (1398 H / 1978 M). al-Mabsut, Juz. 15, Cet. 3. Beirut, Lubnan: Dar al-Ma'arif.

Syamsuddin Muhammad bin Abi al-'Abbas Ahmad bin Hamzah ibi Syihabuddin al-Ramli (1967 M / 1387 H), Nihayat alMuhtaj ila Syarh al-Minhaj, Cet. Terakhir, Juz 6. Mesir: Syarikat Maktabah wa Matba'ah Mustafa al-Babi al-Halabi wa Auladihi.

Syh Noorul Madihah Syed Husin., \& Tengku Fatimah Muliana Tengku Muda. (2011). Konflik antara hak wali mujbir di bawah hukum syarak dan peruntukan had umur minimum perkahwinan. Jurnal Islam dan Masyarakat Kontemporari, 
Keluaran Khas, 7-16.

Wahbah al-Zuhaily. (1985 M / 1405 H). al-Fiqh al-Islami wa Adillatuh, Juz. 7, Cet. 2, Damsyiq: Dar al-Fikr. 